\title{
CGRP and migraine from a cardiovascular point of view: what do we expect from blocking CGRP?
}

\author{
Valentina Favoni ${ }^{1,2^{*}+}$ D, Luca Giani ${ }^{3 \dagger}$, Linda Al-Hassany ${ }^{4 \dagger}$, Gian Maria Asioli ${ }^{1,2 \dagger}$, Calogera Butera ${ }^{5 \dagger}$, Irene de Boer ${ }^{6 \dagger}$, \\ Martina Guglielmetti ${ }^{7,8,9 \dagger}$, Chrysoula Koniari ${ }^{10 \dagger}$, Theodoros Mavridis ${ }^{10 \dagger}$, Marge Vaikjärv ${ }^{11 \dagger}$, Iris Verhagen ${ }^{4,6+}$, \\ Angela Verzina ${ }^{12,13+}$, Bart Zick ${ }^{4,6+}$, Paolo Martelletti ${ }^{7,8+}$, Simona Sacco ${ }^{14,15+}$ and European Headache Federation \\ School of Advanced Studies (EHF-SAS)
}

\begin{abstract}
Calcitonin gene-related peptide (CGRP) is a neuropeptide with a pivotal role in the pathophysiology of migraine. Blockade of CGRP is a new therapeutic target for patients with migraine. CGRP and its receptors are distributed not only in the central and peripheral nervous system but also in the cardiovascular system, both in blood vessels and in the heart. We reviewed the current evidence on the role of CGRP in the cardiovascular system in order to understand the possible short- and long-term effect of CGRP blockade with monoclonal antibodies in migraineurs. In physiological conditions, CGRP has important vasodilating effects and is thought to protect organs from ischemia. Despite the aforementioned cardiovascular implication, preventive treatment with CGRP antibodies has shown no relevant cardiovascular side effects. Results from long-term trials and from real life are now needed.
\end{abstract}

Keywords: CGRP, CGRP antibody, Migraine treatment, Cardiovascular

\section{Introduction}

Migraine is one of the leading chronic neurological disorders, considered among the top five causes of long-term disability and affecting $15 \%$ of the population, mainly women $[1,2]$. Treatments for migraine can be divided into abortive and prophylactic therapy. Calcitonin gene-related peptide (CGRP) blockade has emerged as a therapeutic target for migraine. CGRP is a neuropeptide released from perivascular nerve fibers after trigeminal nerve activation performing a pivotal role in the pathophysiology of migraine $[3,4]$. In recent years, monoclonal antibodies against CGRP and its receptors have been developed and tested in clinical trials involving migraine patients. The site of action

\footnotetext{
* Correspondence: valentina.favoni2@unibo.it

†Valentina Favoni, Luca Giani, Linda Al-Hassany, Gian Maria Asioli, Calogera Butera, Irene de Boer, Martina Guglielmetti, Chrysoula Koniari, Theodoros

Mavridis, Marge Vaikjärv, Iris Verhagen, Angela Verzina, Bart Zick, Paolo Martelletti and Simona Sacco contributed equally to this work.

'Department of Biomedical and Neuromotor Sciences, University of Bologna, Bologna, Italy

${ }^{2}$ IRCCS Istituto delle Scienze Neurologiche di Bologna, Via Altura, 3 Pad. G, 40139 Bologna, Italy

Full list of author information is available at the end of the article
}

of these antibodies is still debated. Because they are large molecules, they have limited potential to pass the blood-brain barrier (BBB) and may act at the peripheral level. However, some studies have shown that brain structures involved in the pathophysiology of migraine (e.g. trigeminal ganglion and the paraventricular structures within the brain stem) are not fully protected by the BBB [5-7], hence effective migraine treatment drugs need not to pass through the BBB. Furthermore, the antimigraine action site may reside in areas not protected by the $\mathrm{BBB}$ such as the intra- and extracranial vessels, dural mast cells, and the trigeminal system [3]. Interestingly, CGRP receptors are located not only in the central and peripheral nervous system but also in the cardiovascular system including blood vessels and the heart [8]. CGRP acts as a very potent vasodilator and plays an important role in regulating vascular resistance and regional organ blood flow in physiological and also during pathological conditions like cerebral or cardiac ischemia [7, 9-11]. We reviewed the current evidence on the role of CGRP in the cardiovascular system to understand the possible short- and long-term effect of CGRP blockade with monoclonal antibodies in migraineurs. 


\section{Methods of review}

Two independent reviewers conducted an independent search on PubMed on July 20th, 2018 using the search terms "cgrp" AND "cardiovascular system" OR "cardiovascular" AND "system". This search generated 1585 abstracts, which were reviewed independently, and articles were selected on the basis of relevance to the present topic. Discrepancies between investigators were rechecked and, if necessary, discussed with a third investigator until consensus was achieved. Every author added additional papers when needed in their respective section. The final reference list was generated on the basis of originality and relevance to the topic of this Review.

\section{Calcitonin gene-related peptide and CGRP receptors}

CGRP, a peptide with 37 amino acid residues, exists in humans in two isoforms, $\alpha$ and $\beta C G R P$, otherwise known as CGRP I and II. Alternative splicing of the CACL1 gene (calcitonin gene) produces, most prominently in the central and peripheral nervous system, $\alpha$ CGRP $[12,13]$. Transcription of the CACLII gene leads to $\beta C G R P$, most abundantly found in the enteric sensory system $[12,13]$. $\alpha$ CGRP and $\beta$ CGRP share $>90 \%$ homology in humans (with only three amino acids being different) [14]. Therefore, it is logical that their biological activity is similar. CGRP is expressed in the peripheral nervous system in thin unmyelinated $\mathrm{C}$ fibers, and at numerous sites in the central nervous system [4, 1517].The synthesis and release of CGRP can be triggered by activation of the transient receptor potential vanilloid subfamily member 1 (TRPV1). One of the ligands of TRPV1, capsaicin, was first used to demonstrate the release of CGRP from sensory neurons [10]. However, the synthesis and release of CGRP is mediated by many factors, which are still being investigated.

CGRP acts by activating multiple receptors [18-20]. The functional CGRP receptor consists of three components: calcitonin-like receptor (CLR), receptor component protein (RCP) which defines the G-protein to which the receptor binds, and receptor activity-modifying protein 1 (RAMP1) [19-21]. RCP links the receptor to an intracellular C protein-mediated signaling pathway, which increases cyclic adenosine monophosphate (cAMP) levels [22]. For updated classification and nomenclature of calcitonin/CGRP family of peptides and receptors see Table 1. CGRP receptors are also present on the smooth muscle cells of human cranial and coronary arteries $[9,23]$. It remains unclear if there is a difference in the expression of CGRP receptors between cranial and coronary arteries, but functional studies suggest a higher expression of CGRP receptors in cranial arteries. Receptor components of CGRP have also been identified in the trigeminal ganglion, cerebral cortex, hippocampus, thalamus, hypothalamus, brainstem, spinal cord and cerebellum [24-26]. As such, CGRP probably has both neural and vascular actions.

\section{Endothelial dysfunction and CGRP in migraineurs}

Various vascular mechanisms have been described in order to explain the role of CGRP in vasodilation of peripheral vascular beds. The presence of an NO- and endothelium-independent pathway, which leads to vascular relaxation, has been observed in smooth muscle cells of most tissues [27, 28]. However, CGRP also has the capability to stimulate the production of $\mathrm{NO}$ by acting via a receptor located on the endothelium. This endothelium-dependent relaxation pathway results in an accumulation of cAMP and production of NO through endothelial protein kinase A/endothelial NO Synthase (PKA/eNOS) signaling. Eventually, NO diffuses into adjacent smooth muscle cells and activates guanylate cyclase. This finally leads to the production of cGMP and relaxation of vessels $[11,28,29]$. The role of endothelium in migraine pathophysiology is still debated. Some studies indicate that migraineurs have an impaired

Table 1 Current classification of human calcitonin-family receptors, subunit composition and respective ligands

\begin{tabular}{|c|c|c|c|c|c|c|c|}
\hline $\begin{array}{l}\text { Receptor } \\
\text { name }\end{array}$ & CGRP & $\mathrm{AM}_{1}$ & $\mathrm{AM}_{2}$ & $\mathrm{AMY}_{1}$ & $\mathrm{AMY}_{2}$ & $\mathrm{AMY}_{3}$ & CTR \\
\hline \multirow{3}{*}{$\begin{array}{l}\text { Receptor } \\
\text { composition }\end{array}$} & CLR & CLR & CLR & \multirow{3}{*}{$\begin{array}{c}\text { CTR } \\
+ \\
\text { RAMP1 }\end{array}$} & \multirow{3}{*}{$\begin{array}{c}\text { CTR } \\
+ \\
\text { RAMP2 }\end{array}$} & \multirow{3}{*}{$\begin{array}{c}\text { CTR } \\
+ \\
\text { RAMP3 }\end{array}$} & \\
\hline & + & + & + & & & & CTR \\
\hline & RAMP1 & RAMP2 & RAMP3 & & & & \\
\hline Ligand & CGRP & AM & $\begin{array}{c}A M- \\
A M 2 / I M D\end{array}$ & CGRP - AMY & AMY & AMY & $\mathrm{CT}$ \\
\hline \multicolumn{8}{|l|}{ Structure } \\
\hline CLR $\square$ & RAMP & RAMP2 & RAMP3 & CGRP & AN & $\mathrm{Al}$ & $\mathrm{CT}$ \\
\hline
\end{tabular}

CGRP Calcitonin Gene-Related Peptide, AM Adrenomedullin, AMY Amylin, CTR Calcitonin Receptor, CLR Calcitonin receptor-like receptor, RAMP receptor activity-modifying proteins, $A M 2 / I M D$ Adrenomedullin 2/Intermedin 
arterial and endothelial function as compared to non-migraineurs [30]. On the contrary, a recent study suggested that the contribution of endothelium to CGRP-induced vasodilation may not be significant [31]. In fact, cutaneous microvascular sensitivity to endothelial and non-endothelial donors including CGRP showed no difference between a group of patients with migraine compared to controls [32]. It has been speculated that alterations at the endothelial level may contribute to the increased risk (approximately 50\%) of several cardiovascular diseases such as ischemic and hemorrhagic stroke, angina and myocardial infarction, which has been observed in several studies that compared migraineurs (with aura) to non-migraineurs [33-38].

\section{Physiological and pathological influence of CGRP on the cardiovascular system}

CGRP release induces relaxation of smooth muscle cells due to an increase in cAMP and leads to activation of protein kinase $\mathrm{A}$, which phosphorylates and opens potassium channels $[39,40]$. In blood vessels, CGRP acts as an extremely potent vasodilator when compared to several known vasodilators such as histamine, prostaglandin E2 and substance P [41]. Even so, CGRP seems to have no pivotal role in the physiological regulation of systemic blood pressure. For instance, blocking CGRP does not affect systemic blood pressure in healthy volunteers [42]. In the heart, CGRP is localized in sensory nerve fibers and around peripheral arteries [9]. There are specific binding sites for CGRP linked to stimulation of adenylate cyclase activity more concentrated in the atrium [43]. In both rats and humans, in addition to its vasodilator effect, intravenous CGRP administration has been shown to cause positive inotropic and chronotropic effects on the heart [44-47]. In physiological conditions, CGRP might act on a more local level, regulating vascular responsiveness and protecting organs from injury. Thus, CGRP may have a cardiovascular protective role. In pathophysiological situations, like hypertension, conflicting observations have been made. Both decreased, increased and unchanged plasma levels of CGRP have been observed in patients with essential hypertension $[48,49]$. While CGRP does not seem to be involved in the physiological regulation of blood pressure, it has a protective role against the development of hypertension. It exerts its action mainly directly on smooth muscle cells in the vessel wall, most prominently in the microvasculature, which is responsible for the majority of the peripheral vascular resistance and thus, the blood pressure $[9,50]$.

Moreover, CGRP given intravenously to patients with congestive heart failure improved myocardial contractility without any consistent change in arterial pressure or heart rate [51]. CGRP causes beneficial effects on physiological cardiac hypertrophy helping the heart to distinguish physiological, exercise-induced from pathological stresses [52].

In addition, CGRP may play an important role in mediation of ischemic preconditioning, the phenomenon in which a tissue is rendered resistant to the deleterious effects of prolonged ischemia. Capsaicin, which evokes CGRP release from sensory nerves, is reported to protect against myocardial injury by ischemia-reperfusion in the isolated perfused rat heart [53]. Moreover, pretreatment with CGRP for 5 min produces a significant protective effect on the ischemic myocardium, as shown by the enhanced post-ischemic myocardial function, the reduced incidence of ventricular arrhythmia, and the attenuated release of creatine phosphate kinase [54]. Some studies have also suggested that the protective role of CGRP against ischemia may be due to induced vasodilation [55]. In the setting of brain ischemia, it might reduce the extent of the infarct zone [56], while in the case of subarachnoid hemorrhage, there is evidence that CGRP is protective against cerebral vasospasm [57-59]. CGRP might be protective also in the setting of chronic cerebrovascular disease (as induced by bilateral carotid stenosis) and the subsequent neuronal injury and cognitive impairment [56].

\section{Sex differences and CGRP pathophysiology}

CGRP plasma levels are higher in women than in men [60]. Cardiovascular benefits of CGRP, such as vasodilatory and hypotensive effects on the arteries [61] and the positive inotropic effects on the myocardium are strongly influenced by fluctuations in female sex hormone levels [62]. Furthermore, sex hormone receptors are found in the trigeminovascular and cardiovascular system and, therefore, it is likely that there is an interaction between female sex hormones and CGRP, but the exact mechanism is still not fully understood [63, 64]. In animal models, females had higher CGRP levels in the medulla and lower expression of CLR, RAMP1 and RCP-encoding mRNA in tissues, compared to males, suggesting that CGRP receptor synthesis, expression or release in the trigeminovascular system may be regulated by fluctuating female sex hormones. Numerous animal and human studies have shown that cyclic fluctuations of ovarian hormones (mainly estrogen) modulate CGRP both in peripheral and central nervous system [65-67]. It is, therefore, reasonable to think that females, in particular, are sensitive to therapeutic effects of CGRP blockade, but also to adverse events. In clinical practice, it would be useful to know whether female migraineurs have an additional higher cardiovascular risk if they are prescribed CGRP monoclonal antibodies for the treatment of migraine. Future studies should assess possible sex differences in the benefits and harms of drugs acting on the CGRP and its receptor. 


\section{Blocking CGRP}

The blockade of the CGRP system has been obtained by different molecules: non-peptide CGRP antagonists also known as "gepants" (olcegepant, telcagepant, ubrogepant, atogepant), monoclonal antibodies against CGRP (eptinezumab, fremanezumab, galcanezumab) and monoclonal antibodies against CGRP receptor (erenumab).

Gepants have demonstrated efficacy in relieving migraine in clinical trials and do not cause direct vasoconstriction. However, olcegepant had to be administered intravenously due to its low oral bioavailability $[68,69]$. Encouraged by the efficacy of blocking CGRP for the treatment of migraine, monoclonal antibodies able to block either CGRP or its receptor were developed. CGRP antibodies have a slower onset of action compared with the CGRP receptor antagonists, which is consistent with the idea of a slower penetration into the interstitial space of the vascular smooth muscle tissue. The inhibition is evident one week after dosing [70]. Moreover, CGRP antibodies might scavenge CGRP for up to 1.5 months [7].

\section{Short-term effects of blocking CGRP}

The cardiovascular safety of short-term CGRP blockade has been widely explored for both CGRP antagonists and for monoclonal antibodies. In animal models, several studies conducted on non-peptidic CGRP-R antagonists (olcegepant) evidenced that short-term blockade of CGRP have no effects on hemodynamic parameters such as heart rate, blood pressure, cardiac output, coronary flow or severity of ischemia were observed in different animal species [71-73]. CGRP antagonism is safe in healthy volunteers; a study demonstrated that the administration of telcagepant at supra-therapeutic dosage did not induce vasoconstriction both in peripheral and central vascular beds in healthy men [74]. Moreover, this drug did not influence treadmill-exercise-time in patients with stable angina [75].

Clinical trials of single-doses of oral telcagepant administered for acute treatment of migraine showed a total absence of cardiovascular side effects in migraine patients $[76,77]$. Only minor adverse events were registered (dry mouth, somnolence, dizziness, nausea, fatigue) [78].

Since the half-life of monoclonal antibodies is longer (21-50 days) [79] than that of non-peptidic CGRP antagonists, the blockade of CGRP has a longer duration. In rats CGRP blocking antibodies inhibit the neurogenic vasodilation, confirming the role of these molecules in treating migraine, but no effect on heart rate and arterial blood pressure was observed [70]. Similar results were obtained using fremanezumab in monkeys, where the effect of single or multiple (once weekly for 14 weeks) injections on cardiovascular parameters were evaluated. No meaningful modifications of ECG parameters, heart rate, and systolic blood pressure were observed in both situations [80]. In another trial, healthy women over 40 years old (mean age 56 years) were monitored for 24 weeks after administration of a single dose of fremanezumab at different dosages. No changes in ECG parameters, nor heart rate or blood pressure were registered [81].

Safety and tolerability data from clinical trials are encouraging for the anti-CGRP monoclonal antibodies for the treatment of both episodic and chronic migraine. All phase II and phase III clinical trials completed so far for the four developed monoclonal antibodies did not show any safety problem concerning the cardiovascular system $[82,83]$. It must be noted that the patients recruited for clinical trials were young (age range 18-65, with a mean of about 40 years) usually without any significant cardiovascular disease. Therefore, the safety profile of this class of drugs in high-risk patients has to be specifically addressed. A randomized, double-blind placebo-controlled study was performed for studying the cardiovascular effect of erenumab in patients with stable angina. In particular, the investigators evaluated the impact of a dose of the drug (iv infusion of $140 \mathrm{mg}$ ) on exercise time during a treadmill test. There was no decrease in treadmill test, so they concluded that the inhibition of CGRP receptor does not worsen myocardial ischemia [84]. One major criticism about this study regards the population selected, which was composed of non-migraineurs; data indicate that migraineurs are at risk for cardiovascular events [34, 36]. Thus, safety of anti-CGRP monoclonal antibodies in migraineurs may be different from that of the general population. Additionally, in that study most patients $(80 \%)$ were males, while migraine is more prevalent in women. As previously discussed, sex hormones influence the activity of CGRP on the vascular tone and female migraineurs are at increased risk of myocardial infarction [85], possibly exposing them to a specific sensitivity to CGRP blockade [77].

\section{Long-term effects of blocking CGRP}

Pre-registration trials are mostly limited to a maximum of 6 months. Considering the role of CGRP in cardiovascular physiology and in the pathophysiology, this time frame could not be enough to exclude effects of blockade in the long run. There is just one published article about a trial longer than 6 months using anti-CGRP drugs [86]. The interim analysis after one year of open label extension of an erenumab trial (EudraCT 2012-005331-90, NCT01952574) among 383 subjects exposed for a median of 575 days reported one case of death in a 52-year-old man with pre-existing cardiovascular risk factors (hypertension, hypercholesterolemia, obesity, familial history) and post-mortem evidence of severe coronary atherosclerosis and use of sympathomimetics. A case of transient exercise-induced myocardial ischemia during a treadmill 
test was confounded by sumatriptan intake $4 \mathrm{~h}$ prior to the event [86]. Considering the presence of confounding factors, these adverse events may be not related to the treatment. However, a limitation of the study is the lack of a placebo group, which makes it difficult to differentiate spontaneously occurring adverse events from adverse events due to erenumab.

In all short- and long-term studies published, investigators have not observed any hypertensive effect of anti-CGRP drugs, nor were any negative effects observed regarding the development or aggravation of cardiac failure, although this last issue was not specifically addressed, there was no specific monitoring, and it is not clear if any patient with heart failure was treated. Moreover, the time frame might be not enough to observe a clinical effect of organ remodeling.

Regarding the cerebrovascular risk of anti-CGRP drugs, no safety issues have emerged from all the trials completed so far.

\section{Conclusions}

In conclusion, CGRP plays an important role in migraine but also in physiological and pathological cardiovascular conditions. We can speculate that CGRP may act as a link between the brain and the heart. Data emerging from trials with CGRP antibodies suggest that this specific blockade of the CGRP pathway is a safe treatment. To our knowledge, no serious adverse events have been reported since approval of anti-CGRP monoclonal antibodies for migraine treatment in May 2018. However, results from long-term trials and real life are particularly awaited in order confirm these encouraging data on the long-term safety of the new migraine preventive drugs.

\section{Acknowledgements}

This manuscript is a product of the program School of Advanced Science promoted by the European Headache Federation (EHF).

\section{Funding}

The School of Advanced Studies (SAS) of the European Headache Federation supported the publication of this study.

\section{Availability of data and materials}

All papers included in this review can be found online.

\section{Authors' contributions}

All Authors equally contributed to the review. LA-H, GMA, CB, IB, VF, LG, MG, CK, TM, MV, IV, AV, BZ are Junior Fellows of EHF-SAS. PM and SS are Senior Fellows of EHF-SAS. All authors contributed with data interpretation, drafting, revision of the manuscript and approved the final manuscript.

Ethics approval and consent to participate

Not applicable.

\section{Consent for publication}

Not applicable.

\section{Competing interests}

The authors declare that they have no competing interests related to the content of the manuscript.

\section{Publisher's Note}

Springer Nature remains neutral with regard to jurisdictional claims in published maps and institutional affiliations.

\section{Author details}

'Department of Biomedical and Neuromotor Sciences, University of Bologna, Bologna, Italy. ${ }^{2}$ RCCCS Istituto delle Scienze Neurologiche di Bologna, Via Altura, 3 Pad. G, 40139 Bologna, Italy. ${ }^{3}$ Ricovero Ferdinando Uboldi, Paderno Dugnano, Italy. ${ }^{4}$ Division of Vascular Medicine and Pharmacology,

Department of Internal Medicine, Erasmus MC, Rotterdam, The Netherlands. ${ }^{5}$ Dipartimento Neurologico e INSPE, IRCCS Ospedale San Raffaele, Milan, Italy. ${ }^{6}$ Department of Neurology, Leiden University Medical Center, Leiden, The Netherlands. ${ }^{7}$ Department of Clinical and Molecular Medicine, Sapienza University, Rome, Italy. ${ }^{8}$ Regional Referral Headache Center, Sant'Andrea Hospital, Rome, Italy. ${ }^{9}$ Department of Clinical Pathology, University of Sassari, Sassari, Italy. ${ }^{10} 1$ st Neurology Department, Aeginition Hospital, School of Medicine, National and Kapodistrian University of Athens, Athens, Greece.

${ }^{11}$ Faculty of Medicine, University of Tartu, Tartu, Estonia. ${ }^{12}$ Neurology Clinic, University of Perugia, Perugia, Italy. ${ }^{13}$ S. Maria della Misericordia Hospital, Perugia, Italy. ${ }^{14} \mathrm{UOC}$ Neurologia e Stroke Unit, Ospedale SS Filippo e Nicola, Avezzano, Italy. ${ }^{15}$ Department of Applied Clinical Sciences and

Biotechnology, University of L'Aquila, L'Aquila, Italy.

Received: 11 December 2018 Accepted: 26 February 2019 Published online: 12 March 2019

References

1. Steiner TJ, Stovner LJ, Birbeck GL (2013 Jan 10) Migraine: the seventh disabler. J Headache Pain 14:1

2. GBD 2016 Disease and Injury Incidence and Prevalence Collaborators (2017 Sep 16) Global, regional, and national incidence, prevalence, and years lived with disability for 328 diseases and injuries for 195 countries, 1990-2016: a systematic analysis for the Global Burden of Disease Study 2016. Lancet 390(10100):1211-1259

3. Edvinsson L (2017 May) The Trigeminovascular pathway: role of CGRP and CGRP receptors in migraine. Headache. 57(Suppl 2):47-55

4. Edvinsson L, Haanes KA, Warfvinge K, Krause DN (2018 Jun) CGRP as the target of new migraine therapies - successful translation from bench to clinic. Nat Rev Neurol 14(6):338-350

5. Edvinsson L, Tfelt-Hansen $P(2008$ Dec) The blood-brain barrier in migraine treatment. Cephalalgia. 28(12):1245-1258

6. Eftekhari S, Salvatore CA, Johansson S, Chen T-B, Zeng Z, Edvinsson L (2015 Mar 10) Localization of CGRP, CGRP receptor, PACAP and glutamate in trigeminal ganglion. Relation to the blood-brain barrier. Brain Res 1600:93-109

7. MaassenVanDenBrink A, Meijer J, Villalón CM, Ferrari MD, Wiping Out CGRP (2016) Potential Cardiovascular Risks. Trends Pharmacol Sci 37(9):779-788

8. Uddman R, Edvinsson L, Ekblad E, Håkanson R, Sundler F (1986 Aug) Calcitonin gene-related peptide (CGRP): perivascular distribution and vasodilatory effects. Regul Pept 15(1):1-23

9. Gulbenkian S, Saetrum Opgaard O, Ekman R, Costa Andrade N, Wharton J, Polak JM et al (1993 Sep) Peptidergic innervation of human epicardial coronary arteries. Circ Res 73(3):579-588

10. Goadsby PJ, Holland PR, Martins-Oliveira M, Hoffmann J, Schankin C, Akerman S (2017) Pathophysiology of migraine: a disorder of sensory processing. Physiol Rev 97(2):553-622

11. Russell FA, King R, Smillie S-J, Kodji X, Brain SD (2014 Oct) Calcitonin generelated peptide: physiology and pathophysiology. Physiol Rev 94(4): 1099-1142

12. Mulderry PK, Ghatei MA, Spokes RA, Jones PM, Pierson AM, Hamid QA et al (1988 Apr) Differential expression of alpha-CGRP and beta-CGRP by primary sensory neurons and enteric autonomic neurons of the rat. Neuroscience. 25(1):195-205

13. Edvinsson L (2015 Aug) CGRP receptor antagonists and antibodies against CGRP and its receptor in migraine treatment. Br J Clin Pharmacol 80(2): 193-199

14. Juaneda C, Dumont Y, Quirion R (2000 Nov) The molecular pharmacology of CGRP and related peptide receptor subtypes. Trends Pharmacol Sci 21(11):432-438

15. Skofitsch G, Jacobowitz DM (1985 Jul-Aug) Calcitonin gene-related peptide: detailed immunohistochemical distribution in the central nervous system. Peptides. 6(4):721-745 
16. Eftekhari S, Warfvinge K, Blixt FW, Edvinsson L (2013 Nov) Differentiation of nerve fibers storing CGRP and CGRP receptors in the peripheral trigeminovascular system. J Pain 14(11):1289-1303

17. Edvinsson L, Warfvinge K (2017 Jan) Recognizing the role of CGRP and CGRP receptors in migraine and its treatment. Cephalalgia. 1: 333102417736900

18. Goltzman D, Mitchell J (1985 Mar) Interaction of calcitonin and calcitonin gene-related peptide at receptor sites in target tissues. Science. 227(4692): 1343-1345

19. Hay DL, Walker CS (2017 Apr) CGRP and its receptors. Headache. 57(4):625-636

20. Hay DL, Garelja ML, Poyner DR, Walker CS (2018) Update on the pharmacology of calcitonin/CGRP family of peptides: IUPHAR review 25. Br J Pharmacol 175(1):3-17

21. Wimalawansa SJ (1996 Oct) Calcitonin gene-related peptide and its receptors: molecular genetics, physiology, pathophysiology, and therapeutic potentials. Endocr Rev 17(5):533-585

22. Evans BN, Rosenblatt MI, Mnayer LO, Oliver KR, Dickerson IM (2000 Oct 6) CGRP-RCP, a novel protein required for signal transduction at calcitonin gene-related peptide and adrenomedullin receptors. J Biol Chem 275(40): 31438-31443

23. Oliver KR, Wainwright A, Edvinsson L, Pickard JD, Hill RG (2002 May) Immunohistochemical localization of calcitonin receptor-like receptor and receptor activity-modifying proteins in the human cerebral vasculature. J Cereb Blood Flow Metab 22(5):620-629

24. Eftekhari S, Salvatore CA, Calamari A, Kane SA, Tajti J, Edvinsson L (2010 Aug 25) Differential distribution of calcitonin gene-related peptide and its receptor components in the human trigeminal ganglion. Neuroscience. 169(2):683-696

25. Unger JW, Lange W (1991 Aug) Immunohistochemical mapping of neurophysins and calcitonin gene-related peptide in the human brainstem and cervical spinal cord. J Chem Neuroanat 4(4):299-309

26. Warfvinge $K$, Edvinsson L (2017 Jan) Distribution of CGRP and CGRP receptor components in the rat brain. Cephalalgia. 1:333102417728873

27. Edvinsson L, Fredholm BB, Hamel E, Jansen I, Verrecchia C (1985 Jul 31) Perivascular peptides relax cerebral arteries concomitant with stimulation of cyclic adenosine monophosphate accumulation or release of an endothelium-derived relaxing factor in the cat. Neurosci Lett 58(2):213-217

28. Brain SD, Grant AD (2004 Jul) Vascular actions of calcitonin gene-related peptide and adrenomedullin. Physiol Rev 84(3):903-934

29. Gray DW, Marshall I (1992 Nov) Human alpha-calcitonin gene-related peptide stimulates adenylate cyclase and guanylate cyclase and relaxes rat thoracic aorta by releasing nitric oxide. Br J Pharmacol 107(3):691-696

30. Sacco S, Ripa P, Grassi D, Pistoia F, Ornello R, Carolei A et al (2013 Oct 1) Peripheral vascular dysfunction in migraine: a review. J Headache Pain. 14:80

31. Edvinsson L, Ahnstedt H, Larsen R, Sheykhzade M (2014 Apr) Differential localization and characterization of functional calcitonin gene-related peptide receptors in human subcutaneous arteries. Acta Physiol (Oxf). 210(4):811-822

32. Edvinsson ML, Edvinsson L (2008 May) Comparison of CGRP and NO responses in the human peripheral microcirculation of migraine and control subjects. Cephalalgia. 28(5):563-566

33. Schürks M, Rist PM, Bigal ME, Buring JE, Lipton RB, Kurth T (2009 Oct 27) Migraine and cardiovascular disease: systematic review and meta-analysis. BMJ. 339:b3914

34. Sacco S, Kurth T (2014 Sep) Migraine and the risk for stroke and cardiovascular disease. Curr Cardiol Rep 16(9):524

35. Kurth T, Winter AC, Eliassen AH, Dushkes R, Mukamal KJ, Rimm EB et a (2016 May 31) Migraine and risk of cardiovascular disease in women: prospective cohort study. BMJ. 353:i2610

36. Sacco S, Ornello R, Ripa P, Tiseo C, Degan D, Pistoia F et al (2015 Jun) Migraine and risk of ischaemic heart disease: a systematic review and meta-analysis of observational studies. Eur J Neurol 22(6):1001-1011

37. Sacco S, Ornello R, Ripa P, Pistoia F, Carolei A (2013 Nov) Migraine and hemorrhagic stroke: a meta-analysis. Stroke. 44(11):3032-3038

38. Sacco S, Ricci S, Carolei A (2012 Jul) Migraine and vascular diseases: a review of the evidence and potential implications for management. Cephalalgia. 32(10):785-795

39. Hirata Y, Takagi Y, Takata S, Fukuda Y, Yoshimi H, Fujita T (1988 Mar 30) Calcitonin gene-related peptide receptor in cultured vascular smooth muscle and endothelial cells. Biochem Biophys Res Commun 151(3): 1113-1121
40. Crossman DC, Dashwood MR, Brain SD, McEwan J, Pearson JD (1990 Jan) Action of calcitonin gene-related peptide upon bovine vascular endothelial and smooth muscle cells grown in isolation and co-culture. Br J Pharmacol 99(1):71-76

41. Brain SD, Tippins JR, Morris HR, Maclntyre I, Williams TJ (1986 Oct) Potent vasodilator activity of calcitonin gene-related peptide in human skin. J Invest Dermatol 87(4):533-536

42. Petersen KA, Birk S, Lassen LH, Kruuse C, Jonassen O, Lesko L et al (2005 Feb) The CGRP-antagonist, BIBN4096BS does not affect cerebral or systemic haemodynamics in healthy volunteers. Cephalalgia. 25(2):139-147

43. Sigrist S, Franco-Cereceda A, Muff R, Henke H, Lundberg JM, Fischer JA (1986 Jul) Specific receptor and cardiovascular effects of calcitonin generelated peptide. Endocrinology. 119(1):381-389

44. Gennari C, Fischer JA (1985 Dec) Cardiovascular action of calcitonin generelated peptide in humans. Calcif Tissue Int 37(6):581-584

45. Gardiner SM, Compton AM, Bennett T (1989 Feb) Regional hemodynamic effects of calcitonin gene-related peptide. Am J Phys 256(2 Pt 2):R332-R338

46. Wang X, Fiscus RR (1989 Feb) Calcitonin gene-related peptide increases CAMP, tension, and rate in rat atria. Am J Phys 256(2 Pt 2):R421-R428

47. Ando K, Pegram BL, Frohlich ED (1990 Feb) Hemodynamic effects of calcitonin gene-related peptide in spontaneously hypertensive rats. Am J Phys 258(2 Pt 2):R425-R429

48. Masuda A, Shimamoto K, Mori Y, Nakagawa M, Ura N, limura O (1992 Dec) Plasma calcitonin gene-related peptide levels in patients with various hypertensive diseases. J Hypertens 10(12):1499-1504

49. Portaluppi F, Trasforini G, Margutti A, Vergnani L, Ambrosio MR, Rossi R et al (1992 Oct) Circadian rhythm of calcitonin gene-related peptide in uncomplicated essential hypertension. J Hypertens 10(10):1227-1234

50. Smillie S-J, King R, Kodji X, Outzen E, Pozsgai G, Fernandes E et al (2014 May) An ongoing role of a-calcitonin gene-related peptide as part of a protective network against hypertension, vascular hypertrophy, and oxidative stress. Hypertension. 63(5):1056-1062

51. Gennari C, Nami R, Agnusdei D, Fischer JA (1990 Mar) Improved cardiac performance with human calcitonin gene related peptide in patients with congestive heart failure. Cardiovasc Res 24(3):239-241

52. Schuler B, Rieger G, Gubser M, Arras M, Gianella M, Vogel O et al (2014 May) Endogenous a-calcitonin-gene-related peptide promotes exercise-induced, physiological heart hypertrophy in mice. Acta Physiol (Oxf) 211(1):107-121

53. D'Alonzo AJ, Grover GJ, Darbenzio RB, Hess TA, Sleph PG, Dzwonczyk S et al (1995 Jan 16) In vitro effects of capsaicin: antiarrhythmic and antiischemic activity. Eur J Pharmacol 272(2-3):269-278

54. Xiao ZS, Li YJ, Deng HW (1996 Sep) Ischemic preconditioning mediated by calcitonin gene-related peptide in isolated rat hearts. Zhongguo Yao Li Xue Bao 17(5):445-448

55. Chai W, Mehrotra S, Jan Danser AH, Schoemaker RG (2006 Feb 15) The role of calcitonin gene-related peptide (CGRP) in ischemic preconditioning in isolated rat hearts. Eur J Pharmacol 531(1-3):246-253

56. Zhai L, Sakurai T, Kamiyoshi A, Ichikawa-Shindo Y, Kawate H, Tanaka M et al (2018 Apr) Endogenous calcitonin gene-related peptide suppresses ischemic brain injuries and progression of cognitive decline. J Hypertens 36(4):876-891

57. Juul R, Aakhus S, Björnstad K, Gisvold SE, Brubakk AO, Edvinsson L (1994 Mar 28) Calcitonin gene-related peptide (human alpha-CGRP) counteracts vasoconstriction in human subarachnoid haemorrhage. Neurosci Lett 170(1): $67-70$

58. Schebesch K-M, Herbst A, Bele S, Schödel P, Brawanski A, Stoerr E-M et al (2013 Apr) Calcitonin-gene related peptide and cerebral vasospasm. J Clin Neurosci 20(4):584-586

59. Johansson SE, Abdolalizadeh B, Sheykhzade M, Edvinsson L, Sams A (2019 Mar 5) Vascular pathology of large cerebral arteries in experimental subarachnoid hemorrhage: vasoconstriction, functional CGRP depletion and maintained CGRP sensitivity. Eur J Pharmacol 846:109-118

60. Valdemarsson S, Edvinsson L, Hedner P, Ekman R (1990 Jun) Hormonal influence on calcitonin gene-related peptide in man: effects of sex difference and contraceptive pills. Scand J Clin Lab Invest 50(4):385-388

61. Al-Rubaiee M, Gangula PR, Millis RM, Walker RK, Umoh NA, Cousins VM et al (2013 Jun 1) Inotropic and lusitropic effects of calcitonin gene-related peptide in the heart. Am J Physiol Heart Circ Physiol 304(11):H1525-H1537

62. Gangula PRR, Wimalawansa SJ, Yallampalli C (2002 Dec) Sex steroid hormones enhance hypotensive effects of calcitonin gene-related peptide in aged female rats. Biol Reprod 67(6):1881-1887 
63. Gupta S, Villalón CM, Mehrotra S, de Vries R, Garrelds IM, Saxena PR et al (2007 Feb) Female sex hormones and rat dural vasodilatation to CGRP, periarterial electrical stimulation and capsaicin. Headache. 47(2):225-235

64. Westley RL, May FEB (2013) A twenty-first century cancer epidemic caused by obesity: the involvement of insulin, diabetes, and insulin-like growth factors. Int J Endocrinol 2013:632461

65. Labastida-Ramírez A, Rubio-Beltrán E, Villalón CM, MaassenVanDenBrink A (2017) Gender aspects of CGRP in migraine. Cephalalgia. 1: 333102417739584

66. Ibrahimi K, van Oosterhout WP, van Dorp W et al (2015) Reduced trigeminovascular cyclicity in patients with menstrually related migraine. Neurology 84:125-131

67. Ibrahimi K, Vermeersch S, Frederiks P, Geldhof V, Draulans C, Buntinx L, de Hoon J (2017) The influence of migraine and female hormones on capsaicin-induced dermal blood flow. Cephalalgia 37(12):1164-1172

68. Doods H, Hallermayer G, Wu D, Entzeroth M, Rudolf K, Engel W et al (2000 Feb) Pharmacological profile of BIBN4096BS, the first selective small molecule CGRP antagonist. Br J Pharmacol 129(3):420-423

69. Olesen J, Diener H-C, Husstedt IW, Goadsby PJ, Hall D, Meier U et al (2004 Mar 11) Calcitonin gene-related peptide receptor antagonist BIBN 4096 BS for the acute treatment of migraine. N Engl J Med 350(11):1104-1110

70. Zeller J, Poulsen KT, Sutton JE, Abdiche YN, Collier S, Chopra R et al (2008 Dec) CGRP function-blocking antibodies inhibit neurogenic vasodilatation without affecting heart rate or arterial blood pressure in the rat. $\mathrm{Br} \mathrm{J}$ Pharmacol 155(7):1093-1103

71. Arulmani U, Schuijt MP, Heiligers JPC, Willems EW, Villalón CM, Saxena PR (2004 Jun) Effects of the calcitonin gene-related peptide (CGRP) receptor antagonist BIBN4096BS on alpha-CGRP-induced regional haemodynamic changes in anaesthetised rats. Basic Clin Pharmacol Toxicol 94(6):291-297

72. Kapoor K, Arulmani U, Heiligers JPC, Willems EW, Doods H, Villalón CM et al (2003 Aug 15) Effects of BIBN4096BS on cardiac output distribution and on CGRP-induced carotid haemodynamic responses in the pig. Eur J Pharmacol 475(1-3):69-77

73. Regan CP, Stump GL, Kane SA, Lynch JJ (2009 Feb) Calcitonin gene-related peptide receptor antagonism does not affect the severity of myocardial ischemia during atrial pacing in dogs with coronary artery stenosis. J Pharmacol Exp Ther 328(2):571-578

74. Van der Schueren BJ, Blanchard R, Murphy MG, Palcza J, De Lepeleire I, Van Hecken A et al (2011 May) The potent calcitonin gene-related peptide receptor antagonist, telcagepant, does not affect nitroglycerin-induced vasodilation in healthy men. Br J Clin Pharmacol 71(5):708-717

75. Chaitman BR, Ho AP, Behm MO, Rowe JF, Palcza JS, Laethem T et al (2012 Mar) A randomized, placebo-controlled study of the effects of telcagepant on exercise time in patients with stable angina. Clin Pharmacol Ther 91(3):459-466

76. Cui X, Ye J, Lin H, Mu J, Lin M (2015 Feb) Efficacy, safety, and tolerability of telcagepant in the treatment of acute migraine: a meta-analysis. Pain Pract 15(2):124-131

77. Chan KY, Vermeersch S, de Hoon J, Villalón CM, Maassenvandenbrink A (2011 Mar) Potential mechanisms of prospective antimigraine drugs: a focus on vascular (side) effects. Pharmacol Ther 129(3):332-351

78. González-Hernández A, Marichal-Cancino BA, MaassenVanDenBrink A, Villalón CM (2018 Jan) Sideeffects associated with current and prospective antimigraine pharmacotherapies. Expert Opin Drug Metab Toxicol 14(1):25-41

79. Raffaelli B, Reuter $U$ (2018 Apr) The biology of monoclonal antibodies: focus on calcitonin gene-related peptide for prophylactic migraine therapy. Neurotherapeutics. 15(2):324-335

80. Walter S, Alibhoy A, Escandon R, Bigal ME (2014 Aug) Evaluation of cardiovascular parameters in cynomolgus monkeys following IV administration of LBR-101, a monoclonal antibody against calcitonin generelated peptide. MAbs. 6(4):871-878

81. Bigal ME, Walter S, Bronson M, Alibhoy A, Escandon R (2014 Oct) Cardiovascular and hemodynamic parameters in women following prolonged CGRP inhibition using LBR-101, a monoclonal antibody against CGRP. Cephalalgia. 34(12):968-976

82. Khan S, Olesen A, Ashina M (2017 Jan) CGRP, a target for preventive therapy in migraine and cluster headache: systematic review of clinical data. Cephalalgia. 1:333102417741297

83. Tso AR, Goadsby PJ (2017 Aug) Anti-CGRP monoclonal antibodies: the next era of migraine prevention? Curr Treat Options Neurol 19(8):27

84. Depre C, Antalik L, Starling A, Koren M, Eisele O, Lenz RA et al (2018 May) A randomized, double-blind, placebo-controlled study to evaluate the effect of Erenumab on exercise time during a treadmill test in patients with stable angina. Headache. 58(5):715-723

85. Mahmoud AN, Mentias A, Elgendy AY, Qazi A, Barakat AF, Saad M et al (2018) Migraine and the risk of cardiovascular and cerebrovascular events: a meta-analysis of 16 cohort studies including 1152407 subjects. BMJ Open 27:8(3):e020498

86. Ashina M, Dodick D, Goadsby PJ, Reuter U, Silberstein S, Zhang F et al (2017 Sep 19) Erenumab (AMG 334) in episodic migraine: interim analysis of an ongoing open-label study. Neurology. 89(12):1237-1243

\section{Ready to submit your research? Choose BMC and benefit from:}

- fast, convenient online submission

- thorough peer review by experienced researchers in your field

- rapid publication on acceptance

- support for research data, including large and complex data types

- gold Open Access which fosters wider collaboration and increased citations

- maximum visibility for your research: over $100 \mathrm{M}$ website views per year

At $\mathrm{BMC}$, research is always in progress.

Learn more biomedcentral.com/submissions 